\title{
Three Cases of Cat Scratch Disease Diagnosed by Indirect Immunofluorescence Antibody Assay and/or Polymerase Chain Reaction of 16S rRNA gene of Bartonella henselae
}

\author{
Soichi MARUYAMA ${ }^{1)}$, Hidenori KABEYA ${ }^{1)}$, Sadao NOGAMI ${ }^{2}$, Hideaki SAKAI $^{3)}$, Junzo SUZUKI $^{4)}$, Hitoshi SUZUKI ${ }^{4}$, \\ Hideo SUGITA ${ }^{5)}$ and Yasuji KATSUBE ${ }^{1)}$ \\ ${ }^{1)}$ Laboratories of Veterinary Public Health and ${ }^{2)}$ Medical Zoology, Department of Veterinary Medicine, College of Bioresource Sciences, \\ Nihon University, 1866 Kameino, Fujisawa, Kanagawa 252-8510, ${ }^{3)}$ Department of Pediatrics, Fukushima Prefectural Aizu General \\ Hospital, 10-75 Shiromae, Aizu-wakamatsu, Fukushima 965-8555, ${ }^{4}$ Department of Pediatrics, Fukushima Medical University School of \\ Medicine, 1 Hikarigaoka, Fukushima, Fukushima 960-1295 and ${ }^{5)}$ Sugita Surgical Clinic, 2-6-2 Kameino, Fujisawa, Kanagawa 252- \\ 0813, Japan
}

(Received 14 March 2000/Accepted 22 August 2000)

ABSTRACT. Three suspected cases of cat scratch disease were diagnosed by indirect immunofluorescence antibody assay and/or polymerase chain reaction. Patient 1 was a 10 -year-old female who presented swelling of the right axial lymph nodes with pain and fever. She kept a kitten, and many scratches were observed on her both legs and dorsum manus. Antibody titers against Bartonella (B.) henselae were 1:32 for IgM 3 weeks after the onset of the symptoms and 1:64 for IgG 8 weeks after the onset. The DNA for 16S rRNA type I of $B$. henselae was detected from the blood sample obtained 3 weeks after the onset of symptoms by polymerase chain reaction for the first time in Japan. Patient 2 was a 22-year-old female veterinary student with a cat scratch at the bottom of her neck by a male kitten. She developed a papule at the scratch, slight fever, and neck pain. Although both Bartonella-specific IgG and IgM antibodies were negative before the scratch, the IgG antibody titer rose to 1:512 14 weeks after the onset. B. henselae was isolated from the kitten and its DNA found to be for $16 \mathrm{~S}$ rRNA type I by PCR. Patient 3 was a 23-year-old female veterinary student with a cat scratch on her left forearm. A small reddish papule developed on the scratch, and she experienced swelling of the left axial lymph node and pain. Both the IgG and IgM antibodies against $B$. henselae were negative before the cat scratch, and the IgG titer rose significantly to $1: 128$ and $1: 1,024$ in 2 and 5 weeks, respectively, after the onset of the symptoms.

KEY WORDS: Bartonella henselae, cat scratch disease, PCR.

J. Vet. Med. Sci. 62(12): 1321-1324, 2000

Cat scratch disease (CSD) is a worldwide zoonosis caused by Bartonella henselae [4, 6, 21] or possibly Bartonella clarridgeiae [9]. In the past, most cases of CSD were diagnosed by clinical manifestations, complaints, and intradermal reaction tests with specimens taken from patients [4] before identification of the causative organism. At present, an indirect immunofluorescence antibody assay (IFA) is widely used for serological diagnosis of CSD $[3,16,19]$. Although the isolation of $B$. henselae from CSD patients is relatively difficult, polymerase chain reaction (PCR) is now available with biopsy specimens of lymph nodes from patients [1, 5] and blood [14] for genetic diagnosis of CSD. In Japan, however, only a few cases of CSD have been identified by laboratory diagnosis including IFA [7] and PCR [15], especially no case has ever been diagnosed by PCR with blood specimens.

This report deals with three CSD cases diagnosed by IFA and/or PCR of $16 \mathrm{~S}$ rRNA of $B$. henselae with blood specimens.

Patient 1: A 10-year-old female child. She has kept a kitten since August 1997 and been often scratched by the kitten. The chief complaints were fever $\left(38-39^{\circ} \mathrm{C}\right)$ and painful right axial lymphadenitis. The painful lymph node appeared on November 4, 1997. The patient consulted a physician 5 days after the onset of lymphadenitis. Although medicated at a private clinic, her symptoms were not improved. She was then sent to the pediatrics department of the Fukushima Pre- fectural Aizu General Hospital and hospitalized for detailed examinations. At hospitalization, her body temperature was $36.5^{\circ} \mathrm{C}$ and many cat scratches were detected on her both legs and dorsum manus (Fig. 1). The right axial lymph node was palpated with pain and measured $5 \times 3 \mathrm{~cm}$ by a computed tomographic scan (Fig. 2). Anemia, splenomegaly, hepatomegaly, and swelling of other lymph nodes were not observed in the patient. Cefotiam dihydrochloride was

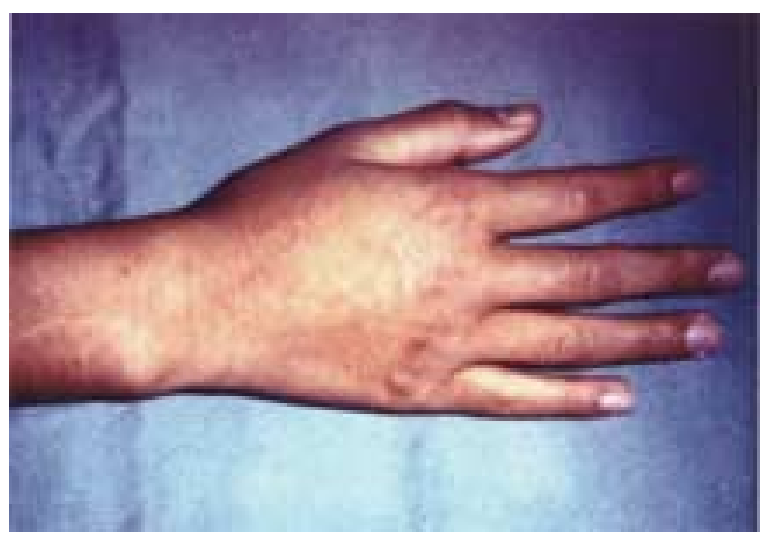

Fig. 1. Many cat scratches are observed on the right dorsum manus of Patient 1 . 


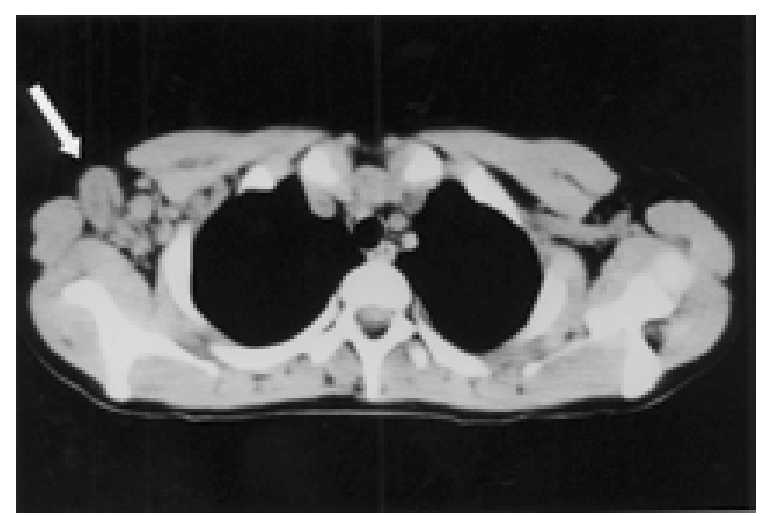

Fig. 2. Axial section of computed tomography of Patient 1 demonstrating the right axially lymph adenopathy (arrow).

administered by intravenous drip infusion. She became afebrile and the pain of the axial lymph node gradually improved after the treatment. An excisional biopsy of the lymph node was performed in 16 days after the onset of symptoms. The biopsy specimen was submitted to the culture of aerobic and anaerobic bacteria, fungi and mycobacteria, and to histopathological examinations by using WarthinStarry stain. The blood samples collected 3 and 8 weeks after the development of lymphadenitis and the biopsy specimen of axial lymph node were sent for laboratory diagnosis of CSD.

Patient 2: A 22-year-old female veterinary student. She was scratched by an experimental male kitten at the bottom of her neck on May 27, 1998. One week later, a small reddish papule appeared on the scratch site. Three weeks after the scratch, the papule became more remarkable and she developed mild fever and fluctuant neck pain. She consulted a physician and then was orally administered Enoxacin for 5 days. This medication did not improve the symptoms, and she again consulted the same clinic. She received intramuscular injection of Dibekacin sulfate for two days and was also orally administered Roxithromycin for 4 days. She completely recovered a week after the medication.

Blood samples were collected 25 weeks before and 14 weeks after the onset of the symptoms and submitted to laboratory diagnosis of CSD. The blood sample from the cat that scratched Patient 2 was also collected 18 weeks after the onset of her symptoms and submitted to quantitative culture of $B$. henselae and detection of $B$. henselae antibodies.

Patent 3: A 23-year-old female veterinary student. She was practicing at a private veterinary clinic in Akashi City, Hyogo Prefecture. An adult male cat was admitted to the clinic for castration. The cat scratched her left forearm during physical examinations in August 1998. Two days after the scratch, she noticed a small reddish papule on the scratch site. Two weeks after the scratch, she developed a swelling of her left axial lymph node with pain, and a reddish papule measured 5-7 $\mathrm{mm}$ in diameter on the scratch site (Fig. 3). The surface of the papule became slightly ulcerated. She was admitted to a private clinic because of hives and lymph-node

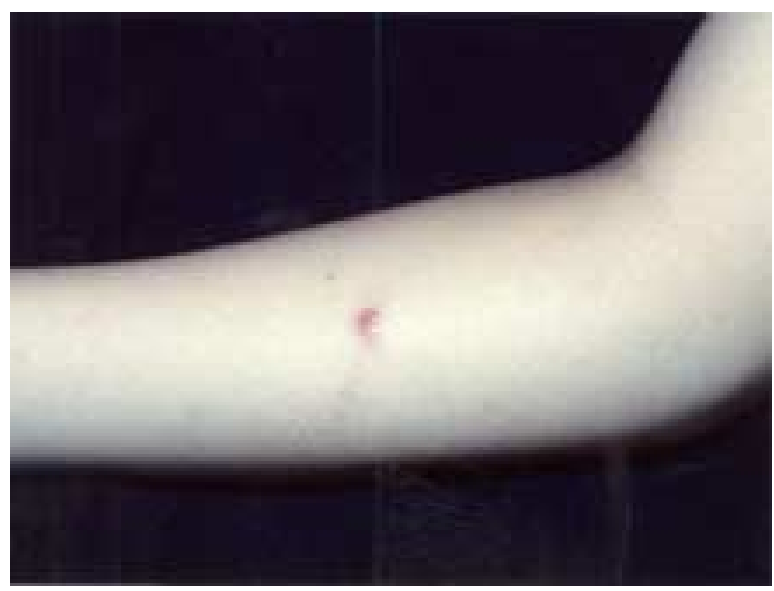

Fig. 3. Reddish papule from the cat scratch on the left forearm of Patient 3.

pain. She was treated with oral administration of Minostatin for several days. The swelling of the lymph node was gradually improved and completely healed in 10 days of medication. Blood samples collected 39 weeks before and 2, 5, and 38 weeks after the onset of the symptoms were submitted to laboratory diagnosis of CSD.

The blood samples were collected in EDTA tubes and submitted to bacterial isolation or genetic examination by PCR. The serum was separated for serological examination of $B$. henselae antibody. All the blood and serum samples from the three patients and a cat blood sample were sent to the Laboratory of Veterinary Public Health, College of Bioresource Sciences, Nihon University. All the samples were stored at $-85^{\circ} \mathrm{C}$ until examined. Bacterial isolation and identification were carried out according to the method previously reported [12].

The antibody titers of the patients against $B$. henselae were determined by IFA with strain $B$. henselae ATCC 49882 . Antigen slides were made by the procedure reported previously [11]. The frozen sera were thawed at room temperature and inactivated at $56^{\circ} \mathrm{C}$ for $30 \mathrm{~min}$. The procedure of IFA for human sera was followed the method previously reported [13]. The cat antibody to $B$. henselae was also examined by the same method as previously reported [11].

The 16S rRNA gene of $B$. henselae in blood samples was amplified by PCR as reported by Bergmans et al. [2] with minor modification. The DNA was extracted with a QIAamp Tissue Kit (QIAGEN, Germany) from $100 \mu l$ of a blood sample obtained from Patient 1 in 3 weeks and Patient 3 in 2 weeks after the onset of the symptoms. No blood sample from Patient 2 was available for Bartonella DNA examination by PCR. The reaction mixture consisted of $20 \mu \mathrm{l}$ of a super Taq premix kit (Sawady Technology Co., Ltd., Japan), $0.5 \mu \mathrm{M}$ of each primer set of $16 \mathrm{SF}$ and $\mathrm{BH} 1$ or $16 \mathrm{SF}$ and $\mathrm{BH} 2$ primers, $10 \mathrm{ng}$ of an extracted DNA sample. DNA was amplified with Zymoreactor II AB-1820 (Atto Corp., Japan) with initial denaturation $\left(95^{\circ} \mathrm{C}, 3 \mathrm{~min}\right)$, followed by 35 cycles of denaturation $\left(95^{\circ} \mathrm{C}, 30 \mathrm{sec}\right)$, annealing $\left(55^{\circ} \mathrm{C}, 90 \mathrm{sec}\right)$ and 
Table 1. Antibody titers after or before onset of CSD symptoms

\begin{tabular}{|c|c|c|c|c|c|c|c|c|c|c|}
\hline \multirow{2}{*}{ Patient } & \multirow{2}{*}{ Antibody } & \multicolumn{9}{|c|}{ Weeks after or before onset } \\
\hline & & -39 & -25 & 2 & 3 & 5 & 8 & 14 & 18 & 38 \\
\hline \multirow{2}{*}{1} & IgG & & & & $\mathrm{N}^{\mathrm{a})}$ & & $1: 64^{\text {b) }}$ & & & \\
\hline & $\operatorname{Ig} M$ & & & & $1: 32$ & & $\mathrm{~N}$ & & & \\
\hline \multirow{2}{*}{2} & $\mathrm{IgG}$ & & $\mathrm{N}$ & & & & & $1: 512$ & cat & \\
\hline & $\operatorname{IgM}$ & & $\mathrm{N}$ & & & & & $\mathrm{N}$ & sample* & \\
\hline \multirow{2}{*}{3} & $\operatorname{IgG}$ & $\mathrm{N}$ & & $1: 128$ & & $1: 1,024$ & & & & $\mathrm{~N}$ \\
\hline & $\operatorname{IgM}$ & $\mathrm{N}$ & & $\mathrm{N}$ & & $\mathrm{N}$ & & & & $\mathrm{N}$ \\
\hline
\end{tabular}

a) $\mathrm{N}$ : Negative. b) Antibody titer. * B. henselae was isolated at a count of $1,984 \mathrm{CFU} / \mathrm{m} l$ from the cat that scratched Patient 2 and the extracted DNA yielded a 16S rRNA type I fragment by PCR. Neither IgG nor Ig M to $B$. henselae was detected from the cat serum.

extension $\left(72^{\circ} \mathrm{C}, 30 \mathrm{sec}\right)$, with a single final extension step $\left(72^{\circ} \mathrm{C}, 9 \mathrm{~min}\right)$. The amplified PCR product was submitted to electrophoresis in a $1.5 \%$ agarose (NuSieve GTG agarose, FMC BioProducts., Rockland, ME, U.S.A.). When a specific band of $185 \mathrm{bp}$ was detected with each of 16SF and BH1 and $16 \mathrm{SF}$ and $\mathrm{BH} 2$ primer set, the strain was identified as type I and type II, respectively.

In Patient 1, Bartonella-specific IgM antibody (1:32) was detected from the serum taken 3 weeks after the onset of the symptoms, but the IgG antibody was negative. The Bartonella-specific IgG antibody (1:64) was found in the sample collected 8 weeks after the onset, but no $\operatorname{IgM}$ was found. In Patient 2, though both of Bartonella-specific IgG and IgM antibodies were negative in the sample taken 25 weeks before onset, the IgG antibody (1:512) was found in the serum taken 14 weeks after onset. In Patient 3, both the IgG and $\operatorname{IgM}$ antibodies were negative 39 weeks before onset. The IgG level in the patient increased to 1:128 2 weeks and reached the highest level $(1: 1,024) 5$ weeks after the onset of the symptoms. However, the IgG antibody was no longer detected 38 weeks after onset (Table 1).

In this study, a significant elevation of antibody against $B$. henselae was found in all three patients after cat scratch, however, the trend of antibody titer was different from one patient to another. Patient 1 produced low levels of Bartonella-specific both IgM and IgG, and high levels of the IgG were detected only in Patient 3. This indicates that there is no standard course of anti- $B$. henselae antibody production in patients with CSD. Similar results have been reported by Bergmans et al. [3].

No bacteria were isolated from any blood sample of the patients or the biopsy specimen of axial lymph node from Patient 1. Warthin-Starry stain was also negative with the biopsy specimen of Patient 1.

B. henselae was isolated at a count of $1,984 \mathrm{CFU} / \mathrm{m} l$ from the cat that scratched Patient 2 in 18 weeks after onset and the extracted DNA yielded a type I fragment by PCR. Neither IgG nor IgM antibody to $B$. henselae was detected from the serum of the cat (Table 1).

The DNA of $B$. henselae 16S rRNA type I was amplified in the blood sample of Patient 1 collected 3 weeks after onset, but no DNA was found in the sample of Patient 3 taken 2 weeks after onset (Fig. 4). No DNA of B. henselae 16S rRNA type II was detected in any of the blood samples examined (data not shown).

In this study, three patients were diagnosed clinically and serologically, and one patient (Patient 1) was genetically diagnosed as CSD. Although no Bartonella was isolated from any of the blood samples examined, the DNA of $B$. henselae type I was detected from the blood of Patient 1 collected 3 weeks after onset. Furthermore, the $\operatorname{IgM}$ antibody was also detected from the same sample. These results suggest that the patient was infected with $B$. henselae type I and developed bacteremia in an early stage of CSD. Our result seems to be the first case of CSD diagnosed by IFA and PCR of $B$. henselae $16 \mathrm{~S}$ rRNA gene from the blood of a patient in Japan. The detection of $B$. henselae DNA from clinical specimens seems to be easier than the isolation of the organism as described in other reports $[1,5,18]$. Therefore, genetic identification of $B$. henselae DNA from blood by PCR is a useful and reliable tool for laboratory confirmation of CSD in an early stage.

The prevalence of $16 \mathrm{~S}$ rRNA gene type of $B$. henselae was different depending upon countries examined. In the Netherlands, type I of $B$. henselae was more prevalent in the isolates from CSD patients than was type II [2]. In Germany, the type II was isolated more frequently from cats [17] and the DNA of $B$. henselae genotype II was detected in two of three children with CSD [18]. On the other hand, type I was the predominant gene type among pet cats in Japan [12]. In this study, the DNA of $B$. henselae type I was detected from Patient 1, suggesting that the cat implicated in Patient 1 may harbor gene type I of $B$. henselae. Furthermore, $B$. henselae type I was isolated from the cat that scratched Patient 2. These facts suggest that type I may be a significant gene type for CSD in Japan.

All the patients had some association with cat scratch and showed significant antibody elevation after typical clinical manifestation of CSD. Especially, a high number of $B$. henselae type I was isolated from the cat that scratched Patient 2. These results strongly suggest that cats are the major reservoir of CSD. The seroprevalence against $B$. henselae in cats was reported to range from $6.3 \%$ in the northeastern area to $22.0 \%$ in the central area of Japan [20]. 


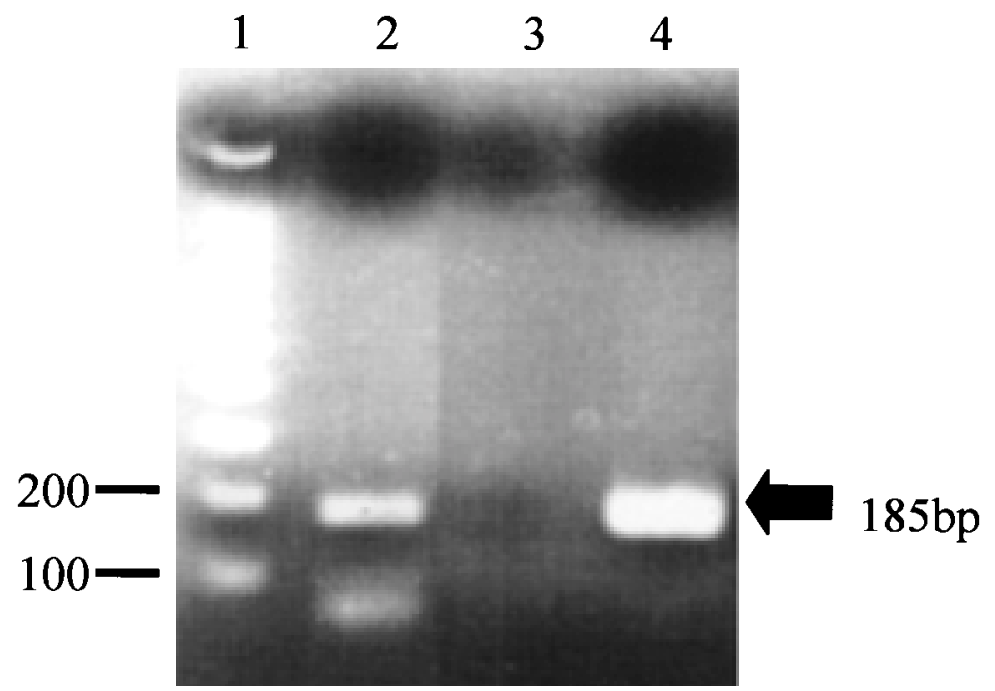

Fig. 4. Detection of Bartonella $16 \mathrm{~S}$ rRNA type I by PCR with $16 \mathrm{SF}$ and BH1 primers. Lane 1; size standard, lane 2; blood sample from Patient 1, lane 3; blood sample from Patient 3, lane 4; sample DNA from Bartonella henselae ATCC 49882.

In Kanto district, the central area of Japan, $9.1 \%$ of pet cats were found to be seropositive against $B$. henselae [11]. Furthermore, Maruyama et al. [12] reported that from $2.0 \%$ of cats in Niigata (northeastern Japan) to $20 \%$ of those in Okinawa (southwestern Japan) harbored $B$. henselae and/or $B$. clarridgeiae in their blood. These data suggest that bacteremic cats are widely distributed and may serve as potential sources of Bartonella infection for human beings in Japan. Furthermore, cats were reported to show prolonged bacteremia of the organism [8]. Therefore, it is necessary to pay much attention to pet cats as a source of CSD.

ACKNOWLEDGEMENTS. The authors thank Misses R. Nakao, K. Nogami and T. Shinohara, and Mr. S. Ishioka, the Laboratory of Veterinary Public Health, College of Bioresource Sciences, Nihon University for their technical assistance.

\section{REFERENCES}

1. Anderson, B., Sims, K., Regnery, R., Robinson, L., Schmidt, M. J., Goral, S., Hager, C. and Edwards, K. 1994. J. Clin. Microbiol. 32: 942-948.

2. Bergmans, A. M., Schellekens, J. F., van Embden, J. D. and Schouls, L. M. 1996. J. Clin. Microbiol. 34: 254-260.

3. Bergmans, A. M., Peeters, M. F., Schellekens, J. F., Vos, M. C., Sabbe, L. J., Ossewaarde, J. M., Verbakel, H., Hooft, H. J. and Schouls, L. M. 1997. J. Clin. Microbiol. 35: 1931-1937.

4. Carithers, H. A. 1985. Am. J. Dis. Child. 139: 1124-1133.

5. Goral, S., Anderson, B., Hager, C. and Edwards, K. M. 1994. Pediatr. Infect. Dis. J. 13: 994-997.

6. Hamilton, D. H., Zangwill, K. M., Hadler, J. L. and Cartter, M. L. 1995. J. Infect. Dis. 172: 570-573.

7. Kado, Y., Emura, A., Hosoi, G., Fujita, H., Sako, M., Shiomi, M. and Ikeda, T. 1999. J. Jpn. Pediatr. Soc. 103: 451-454 (in Japanese).
8. Kordick, D. L., Wilson, K. H., Sexton, D. J., Hadfield, T. L., Berkhoff, H. A. and Breitschwerdt, E. B. 1995. J. Clin. Microbiol. 33: 3245-3251.

9. Kordick, D. L., Hilyard, E. J., Hadfield, T. L., Wilson, K. H., Steigerwalt, A. G., Brenner, D. J. and Breitschwerdt, E. B. 1997. J. Clin. Microbiol. 35: 1813-1818.

10. Maruyama, S., Nogami, S., Inoue, I., Namba, S., Asanome, K. and Katsube, Y. 1996. J. Vet. Med. Sci. 58: 81-83.

11. Maruyama, S., Hiraga, S., Yokoyama, E., Naoi, M., Tsuruoka, Y., Ogura, Y., Tamura, K., Namba, S., Kameyama, Y., Nakamura, S. and Katsube, Y. 1998. J. Vet. Med. Sci. 60: 997-1000.

12. Maruyama, S., Nakamura, Y., Kabeya, H., Tanaka, S., Sakai, T. and Katsube, Y. 2000. J. Vet. Med. Sci. 62: 273-279.

13. Maruyama, S., Boonmar, S., Morita, Y., Sakai, T., Tanaka, S., Yamaguchi, F., Kabeya, H. and Katsube, Y. 2000. J. Vet. Med. Sci. 62: 635-637.

14. Matar, G. H., Koehler, J. E., Malcolm, G., Lambert-Fair, M. A., Tappero, J., Hunter, S. B. and Swaminathan, B. 1999. J. Clin. Microbiol. 37: 4045-4047.

15. Murano, I., Yoshii, H., Kurashige, H., Sugio, Y., Uchida, M., Shinohara, T., Tsuneoka, H., Yamamoto, K., Iino, H., Fujii, R., Fujisawa, K. and Tsukahara, M. 1999. J. Jpn. Assoc. Infect. Dis. 73: 248--252 (in Japanese).

16. Regnery, R. L., Olson, J. G., Perkins, B. A. and Bibb, W. 1992. Lancet 339: 1443-1445.

17. Sander, A., Ruess, M., Bereswill, S., Schuppler, M. and Steinbrueckner, B. 1998. J. Clin. Microbiol. 36: 2973-2981.

18. Sander, A., Ruess, M., Deichmann, K., Bohm, N. and Bredt, W. 1998. Scand. J. Infect. Dis. 30: 387-391.

19. Sander, A., Posselt, M., Oberle, K. and Bredt, W. 1998. Clin. Diagn. Lab. Immunol. 5: 486-490.

20. Ueno, H., Muramatsu, Y., Chomel, B. B., Hohdatsu, T., Koyama, H. and Morita, C. 1995. Microbiol. Immunol. 39: 339341 .

21. Yoshida, H., Kusaba, N., Omachi, K., Miyazaki, N., Yamawaki, M., Tsuji, Y., Nakahara, K., Sumino, M., Noudomi, M., Shimokawa, Y. and Tanikawa, K. 1996. Microbiol. Immunol. 40: 671-673. 